\title{
Medikamenter er til hjelp ved alkoholavhengighet
}

\author{
Legemidlene akamprosat og naltrekson kan hindre tilbakefall hos \\ alkoholavhengige.
}

Alkoholrelaterte lidelser er vanlig, og de forårsaker betydelig sykelighet og dødelighet. Medikamenter mot alkoholavhengighet er imidlertid lite brukt. Effekten av slike medikamenter er undersøkt $i$ en ny systematisk oversikt og metaanalyse (1).

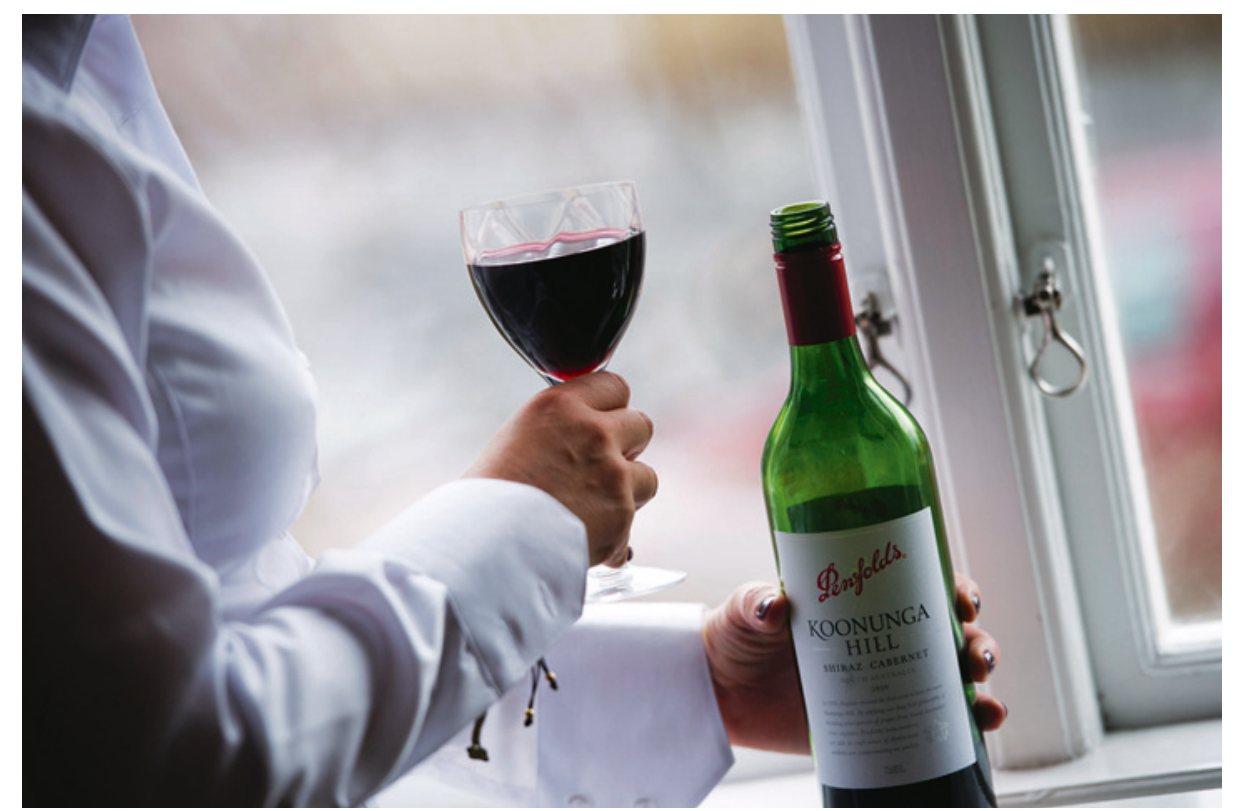

Illustrasjonsfoto: NTB scanpix
En stor kohortstudie og 122 randomiserte, kontrollerte forsøk ble inkludert i analysen. I de fleste studiene ble medikamentene akamprosat og naltrekson undersøkt. Antallet alkoholavhengige som måtte behandles med akamprosat for at én skulle unngå å

gjenoppta sin alkoholbruk (numbers needed to treat, NNT) var 12. Tilsvarende tall for naltrekson var 20 . I en metaanalyse av forsøk der effekten av de to medikamentene ble sammenliknet, var det ingen statistisk signifikante forskjeller når det gjaldt tilbakefall til alkoholbruk.

- Undersøkelsen er en grundig systematisk kunnskapsoppsummering og metaanalyse av betydningen av farmakoterapi ved alkoholavhengighet. Det viktigste budskapet er at bruk av legemidlene akamprosat og naltrekson kan redusere alkoholinntaket hos alkoholavhengige, men at effektene er relativt moderate, sier Jørg Mørland, spesialist i klinisk farmakologi og seniorforsker ved Avdeling for rusmiddelforskning og metodeutvikling, Divisjon for rettsmedisinske fag, Nasjonalt folkehelseinstitutt.

- Det er viktig å bemerke at pasientene også fikk omfattende psykososial behandling og at det var den medikamentelle tilleggsvirkningen som ble studert. Resultatene taler for at disse legemidlene bør benyttes som et terapeutisk supplement hos pasienter med både moderate og alvorlige alkoholproblemer, sier Mørland.

\section{Sigurd Høye \\ Tidsskriftet \\ Litteratur \\ 1. Jonas DE, Amick HR, Feltner $C$ et al. Pharmaco- therapy for adults with alcohol use disorders in outpatient settings: a systematic review and meta- analysis. JAMA 2014: 311: 1889-900.}

\section{Screening for tykktarmskreft - hvilken metode er best?}

\section{Screening ved bruk av koloskopi synes å være mer effektivt i å fore- bygge død av proksimal tykktarms- kreft enn sigmoidoskopiscreening}

Norge er blant landene i verden med høyest forekomst av kolorektal kreft, og innføring av landsdekkende screening for denne kreftformen er gjenstand for diskusjon. Nå har tyske forskere i en metaanalyse sammenliknet screeningeffekten av sigmoidoskopi og koloskopi (1).

I fire randomiserte studier og ti observasjonsstudier var det en betydelig reduksjon i distal, men ikke proksimal insidens og mortalitet av kolorektal kreft ved sigmoidoskopiscreening. Når det gjaldt screening med koloskopi, var det bare seks observasjonsstudier, men antydning til enda større nedgang $\mathrm{i}$ insidens og mortalitet av distal kolorektal kreft og en signifikant reduksjon i mortalitet av kreft i proksimale colon. Sammenlikning av resultatene tydet på $40-60 \%$ lavere risiko for å utvikle og dø av kolorektal kreft ved koloskopiscreening enn ved sigmoidoskopiscreening.

- Effekten av sigmoidoskopiscreening er velkjent, sier overlege og stipendiat Kjetil Kjeldstad Garborg ved Sørlandet sykehus Kristiansand. - Det nye er metaanalyse av observasjonelle sigmoidoskopi- og koloskopiscreeningstudier. Ikke uventet finner de at koloskopiscreening har størst effekt på insidens og dødelighet. Men koloskopiscreening er mer belastende og kan føre til lavere deltakelse enn sigmoidoskopiscree- ning, så effekten på populasjonsnivå kan jevne seg ut. Det hefter risiko for utvalgsskjevhet ved observasjonsstudiene, og viktige faktorer som komplikasjoner og kostnader ved screening kan ikke evalueres. Vi må avvente resultatene av pågående randomiserte studier for å si noe om hvor egnet koloskopi er for populasjonsbasert screening, sier Kjeldstad Garborg.

Trine B. Haugen

Tidsskriftet

\section{Litteratur}

1. Brenner B, Stock C, Hoffmeister M. Effect of screening sigmoidoscopy and screening colonoscopy on colorectal cancer incidence and mortality: systematic review and meta-analysis of randomised controlled trials and observational studies. BMJ 2014; 348: g2467. 